\title{
Mechanisms involved in the intestinal absorption of dietary vitamin A and provitamin A carotenoids *
}

\author{
Earl H. Harrison * \\ Department of Human Nutrition, The Ohio State University, 350 Campbell Hall, 1787 Neil \\ Avenue, Columbus OH 43210, USA
}

\begin{abstract}
Vitamin A is an essential nutrient for humans and is converted to the visual chromophore, 11-cisretinal, and to the hormone, retinoic acid. Vitamin A in animal-derived foods is found as long chain acyl esters of retinol and these are digested to free fatty acids and retinol before uptake by the intestinal mucosal cell. The retinol is then reesterified to retinyl esters for incorporation into chlylomicrons and absorbed via the lymphatics or effluxed into the portal circulation facilitated by the lipid transporter, ABCA1. Provitamin A carotenoids such as $\beta$-carotene are found in plantderived foods. These and other carotenoids are transported into the mucosal cell by scavenger receptor class B type I (SR-BI). Provitamin A carotenoids are partly converted to retinol by oxygenase and reductase enzymes and the retinol so produced is available for absorption via the two pathways described above. The efficiency of vitamin A and carotenoid intestinal absorption is determined by the regulation of a number of proteins involved in the process. Polymorphisms in genes for these proteins lead to individual variability in the metabolism and transport of vitamin A and carotenoids. This article is part of a Special Issue entitled Retinoid and Lipid Metabolism.
\end{abstract}

\section{Keywords}

Retinoid; Carotenoid; Membrane transport; Lipid; Chylomicron; Metabolism

\section{Introduction}

Vitamin A deficiency affects more than 100 million children throughout the world [1,2]. Thus, knowledge about the mechanisms of absorption of vitamin A can lead to better approaches for enhancing its absorption and could be helpful in ameliorating some of the deficiencies.

Capability for the de novo synthesis of compounds with vitamin A activity is limited to plants and microorganisms $[3,4]$. Thus, higher animals must obtain vitamin A from the diet, either as the preformed vitamin or as a provitamin carotenoid such as $\beta$-carotene. In the intestinal mucosa $\beta$-carotene is converted to retinal by $\beta$-C $15,15^{\prime}$ oxygenase 1 (BCO1) and the retinal is then reduced to retinol by a retinal reductase [5]. In the human intestine about half the dietary provitamin A carotenoids are converted to retinol and about half are absorbed intact [6] although the extent of conversion varies widely among individuals. The major dietary forms of preformed vitamin A are long-chain fatty acid esters of retinol [7]. These esters must be hydrolyzed prior to intestinal absorption. Hydrolysis of the esters is

\footnotetext{
This article is part of a Special Issue entitled Retinoid and Lipid Metabolism.

(C) 2012 Published by Elsevier B.V.

*Tel.: +1 614292 8189; fax: +1 614292 8880. Harrison.304@ osu.edu.
} 
catalyzed both by enzymes secreted by the pancreas into the intestinal lumen and by those associated directly with intestinal cells.

Following the hydrolysis of dietary retinyl esters, the free retinol is then taken up by the mucosal cell [8]. The free retinol, resulting either from hydrolysis of dietary retinyl esters or conversion of dietary provitamin A carotenoids, is reesterified with long-chain, mainly saturated, fatty acids by the enzyme lecithin:retinol acyltransferase (LRAT) when physiological doses of vitamin A are ingested [9,10]. The resulting retinyl esters are incorporated with other neutral lipid esters (i.e., triacylglycerols and cholesteryl esters) and intact carotenoids into chylomicrons and absorbed via the lymphatics [11,12]. In the vascular compartment much of the chylomicron triacylglycerol is hydrolyzed by lipoprotein lipase in extrahepatic tissues resulting in the production of a "chylomicron remnant" that contains most of the newly-absorbed retinyl esters $[13,14]$. In the rat, the chylomicron remnants are rapidly and almost quantitatively taken up by the liver, and there is evidence that the retinyl esters are rapidly hydrolyzed and reesterified during this process [15-17].

\section{Dietary sources and luminal factors}

As mentioned above, vitamin A activity in the diet derives from two sources: preformed vitamin A as retinyl esters in foods of animal origin and provitamin A carotenoids, such as $\beta$-carotene, $a$-carotene, and $\beta$-cryptoxanthin, found in plant derived foods. Stoichiometric conversion of $1 \mathrm{~mol}$ of $\beta$-carotene (with $2 \beta$-ionone rings) would give rise to $2 \mathrm{~mol}$ of retinol (via retinal), whereas conversion of a mole of either $\beta$-cryptoxanthin or $\alpha$-carotene (each with only a single $\beta$-ionone ring) would give rise to a single mole of retinol. $\beta$-Carotene is the most potent vitamin A precursor of all provitamin A carotenoids. In order to exhibit a provitamin A activity, the carotenoid molecule must have at least one unsubstituted $\beta$ ionone ring and the correct number and position of methyl groups in the polyene chain [18]. In practice, $\alpha$-C, $\beta$-cryptoxanthin, and $\gamma$-carotene show 30 to $50 \%$ of provitamin A activity $[19,20]$ and 9 -cis and 13-cis isomers of $\beta$-C less than $10 \%$ [21], compared to all-trans $\beta$-C.

Foods in the US diet with the highest concentrations of preformed vitamin A are avian and mammalian livers (4-20 $\mathrm{mg}$ retinol/100 g), instant powdered breakfast drinks (3-6 mg/100 g), ready-to-eat cereals $(0.7-1.5 \mathrm{mg} / 100 \mathrm{~g}$ ), and margarines (about $0.8 \mathrm{mg} / 100 \mathrm{~g}$ ) [22]. Other than liver, the other sources derive their high retinyl ester contents from fortification. The highest concentrations of vitamin A as provitamin A carotenoids are found in carrots, sweet potatoes, pumpkin, kale, spinach, collards and squash (roughly 5-10 mg retinol activity equivalents per $100 \mathrm{~g}$ ) [22]. A retinol activity equivalent (RAE) is equal to $1 \mu \mathrm{g}$ retinol or 12 $\mu \mathrm{g} \beta$-carotene, or $24 \mu \mathrm{g}$ of $a$-carotene or $\beta$-cryptoxanthin [23]. In the United States the major contributors to the intake of preformed vitamin A are milk, margarine, eggs, beef liver, and ready-to-eat cereals, while the major sources of provitamin A carotenoids are carrots, cantaloupes, sweet potatoes and spinach. Analysis of NHANES data [24], for both genders and all age groups, showed that the mean intake of vitamin A in the US was about $600 \mu \mathrm{g}$ RAE/day from food and that $70-75 \%$ of this was as preformed vitamin A (retinol). The provitamin A carotenoids $\beta-\mathrm{C}, \mathrm{a}-\mathrm{C}$, and $\beta$-cryptoxanthin were ingested in amounts of approximately 1750,350 , and $150 \mu \mathrm{g} /$ day, respectively.

It is clear from studies both in experimental animals and humans that the coingestion of dietary fat markedly enhances the intestinal absorption of dietary vitamin A and carotenoids $[25,26]$. The presence of dietary fat in the intestine can stimulate retinyl ester digestion and provitamin A conversion by [1] stimulating pancreatic enzyme secretion, [2] stimulating the secretion of bile salts, which serve to form mixed micelles of lipids, and [3] providing products of lipid digestion (i.e., lysophospholipids, monoglycerides, and free fatty acids), which themselves can serves as components of micelles. Finally, fat ingestion promotes 
vitamin A and carotenoid absorption by providing the lipid components for intestinal chylomicron assembly, a process discussed in more detail below.

\section{Conversion of provitamin A carotenoids to retinoids}

Two pathways have been described for the cleavage of $\beta-\mathrm{C}$ to retinoids (vitamin A): central and eccentric (Fig. 1). The major pathway is the central cleavage catalyzed by a cytosolic enzyme, $\beta$-C 15,15' -oxygenase 1 (BCO1), which cleaves $\beta$-C at its central double bond $\left(15,15^{\prime}\right)$ to yield retinal, a direct precursor of retinol and retinoic acid. Two mechanisms for the enzymatic central cleavage of $\beta-C$ have been proposed. The first is a dioxygenase reaction that requires molecular oxygen and yields an unstable dioxetane intermediate that is rapidly converted into retinal [27]. More recently, a monooxygenase reaction mechanism that requires two oxygen atoms from two different sources (molecular oxygen and water) and yields an epoxide as intermediate has been proposed [28].

Regardless of the mechanism, the final product of the central cleavage of $\beta-\mathrm{C}$ is retinal. Using intestinal preparations, the stoichiometry of this reaction was clearly shown to be 2 mol of retinal formed per $1 \mathrm{~mol}$ of $\beta-\mathrm{C}$ cleaved [29,30]. BCO1 has now been characterized on a molecular level in Drosophila melanogaster [31], chicken [32], mouse [5,33,34], and human [35]. In these different species, the identified cDNA sequence encoded a protein with the ability to catalyze the cleavage of $\beta-C$ into retinal and consisting of $\sim 550$ amino acids (with a predicted molecular weight of $\sim 65 \mathrm{kDa}$ ). This sequence is well conserved among the different species and showed a high sequence homology with RPE65, a retinal pigment epithelium enzyme that catalyzes the conversion of retinyl esters to 11-cis-retinol. Although the purification of the recombinant human protein showing a specific activity of $10 \mathrm{nmol}$ retinal/min/mg protein has been successfully achieved [36], much remains to be known about the enzymology of BCO1.

The second pathway of $\beta-\mathrm{C}$ metabolism is the eccentric cleavage, which occurs at double bonds other than the central $15,15^{\prime}$-double bond of the polyene chain of $\beta$-C to produce $\beta$ apo-carotenals with different chain lengths. Given that only trace amounts of apocarotenals are detected in vivo from tissues of animals fed $\beta-C$ [37] and the fact that they can be formed non-enzymatically from $\beta-\mathrm{C}$ auto-oxidation [38], the existence of this pathway had been the subject of debate. However, the identification and characterization of an eccentric cleavage enzyme from mouse that acts specifically at the $9^{\prime}, 10^{\prime}$-double bond of $\beta$-C to produce $\beta$-apo- $10^{\prime}$-carotenal and $\beta$-ionone [39], provide evidence for the occurrence of some eccentric cleavage in animals. Based on in vitro observations [40], it was suggested that eccentric cleavage could occur preferentially under oxidative conditions (when antioxidants are insufficient) such as smoking and diseases involving an oxidative stress and/or in the presence of high $\beta$-C levels. In contrast, under normal physiological conditions (when antioxidants are adequate), central cleavage would be the predominant pathway.

The two major sites of $\beta-C$ conversion to vitamin $A$ in humans are the intestine and liver. By direct determination of BCO1 activity in human small intestine and liver samples, it was estimated that in a human adult the maximum capacity for $\beta$-C cleavage by the two organs combined was $12 \mathrm{mg} \beta$-C/day [41]; this amount is much higher than the observed average daily intake of $1.5 \mathrm{mg} \beta$-C/day in the United States. Human liver was shown to have 4 times the capacity for metabolizing $\beta-C$ than the small intestine [41]. This is consistent with the earlier prediction, using a multicompartmental model, that in humans $\beta$-C cleavage takes place in the liver to a greater extent than in the intestine [42]. In rats, the highest activities of $\mathrm{BCO} 1$ were also found in the small intestine and liver followed by the brain, lung and kidney [43]. In agreement with the tissue distribution of the BCO1 activity, high levels of human BCO1 mRNA were reported in the jejunum, liver and kidney, whereas lower levels 
were present in the prostate, testis, ovary and skeletal muscle [36]. In contrast to humans, rats convert most of $\beta-\mathrm{C}$ in the intestine and only small amounts of $\beta-\mathrm{C}$ reach the liver [12].

In rats $\mathrm{BCO} 1$ activity was enhanced by vitamin A deficiency [44], dietary polyunsaturated fats [45], copper depletion and fructose feeding [46] and inhibited by protein deficiency [47]. A direct repeat of retinoic acid response elements (RAREs) was identified in the promoter of the mouse BCO1 gene, suggesting that retinoic acid (RA) and 9-cis RA could down-regulate the intestinal enzyme in rat and chicken at the transcriptional level via their interaction with retinoic acid receptors (RAR) and/or retinoid X receptors (RXR) [48]. This mechanism of regulation could be generalized to all pro-RA retinoids and carotenoids and explains why vitamin A deficiency status enhanced the intestinal enzyme activity [49]. The mechanism involves the RA-dependent induction of the intestinal transcription factor, ISX, and the subsequent ISX-induced repression of BCO1 expression [50]. The molecular and dietary regulation of $\mathrm{BCO} 1$ has been the subject of two excellent, recent reviews [49,51].

\section{Digestion of retinyl esters}

More than four decades ago Erlanson and Borgstrom [52] reported the partial separation of two different pancreatic retinyl ester hydrolase (REH) activities in the rat using a Sephadex G100 column. These two activities hydrolyzed different physical forms of the retinyl palmitate substrate; the early peak mainly hydrolyzed retinyl palmitate, which was dispersed in millimolar concentrations of taurodeoxycholate (a condition known to stimulate carboxylester lipase (CEL) and to inhibit pancreatic triglyceride lipase (PTL) [53]), whereas the subsequent peak was more effective in hydrolyzing dispersed retinyl palmitate in the absence of bile salt. These two different REH elution patterns were consistent with CEL and PTL, respectively.

Pancreatic carboxylester lipase catalyzes the hydrolysis of cholesteryl esters, triglycerides, and lysophospholipids. It was thought to hydrolyze retinyl esters also in the intestine. CEL knockout (CEL KO) mice were generated to study the functions of CEL [54,55]. Though neither CEL KO nor wild type mice absorbed non-hydrolyzable cholesteryl ether, CEL KO mice absorbed about half the amount of cholesterol provided as cholesteryl ester compared to wild type mice. These data indicated that hydrolysis of cholesteryl esters is necessary prior to absorption, and that CEL plays an important role in cholesterol absorption. In contrast to the results for cholesteryl ester, CEL KO mice absorbed the same amount of retinol, when provided as retinyl ester, as did wild type mice. On the other hand, neither mouse absorbed the non-hydrolyzable retinyl hexadecylether. These data suggested that retinyl ester hydrolysis was required for absorption and that CEL was not the responsible enzyme (at least under conditions where the amount of dietary retinyl ester was in the $\mu \mathrm{g}$ range, as used in this study). Triglyceride absorption was also comparable between CEL KO and wild type mice indicating that absence of CEL does not affect triglyceride hydrolysis. Therefore, if intestinal retinyl ester absorption is unaffected in CEL KO mice, one or more other retinyl ester hydrolytic enzymes must be present in the gut lumen or on the enterocyte surface.

Studies were then conducted to identify the non-CEL pancreatic REH activity that appeared to be present in CEL KO mice, as well as to investigate this activity in WT mice and in rats. Several lines of evidence suggested that this activity is due to PTL [56]. In addition, it has been demonstrated that purified pancreatic lipase-related protein-2 (PLRP-2) but not the related PLRP-1 can catalyze the hydrolysis of retinyl palmitate in vitro, but the activity was about one-third that of PTL [57]. Thus, more than one enzyme may be responsible for the complete hydrolysis of retinyl esters in the intestinal lumen. 
In addition to pancreatic bile salt-dependent REH activities, an REH activity intrinsically located in the brush border membrane of the absorptive enterocytes was shown in rat and human intestines $[58,59]$. This enzyme activity was suggested to be due to an intestinal phospholipase B (PLB) [60]. Thus, it is likely that PLB all contribute to retinyl ester digestion. In order to determine their relative roles in intestinal RE digestion and absorption, it is essential to perform RE absorption experiments in the appropriate knock-out mice strains and mice deficient in more than one digestive enzyme.

\section{Intestinal absorption of carotenoids}

Knowledge about human carotenoid absorption is mostly derived from studies conducted with $\beta-C$ [61-64]. Rodents, because of their high efficiency of cleaving provitamin A carotenoids in intestine, are not a good animal model for studying human carotenoid absorption. As alternatives, ferrets, preruminant calves, and gerbils have been used [65-67]. However, none of these animal models completely mimics carotenoid metabolism in humans [68]. Approaches using stable isotopes, coupled with mass spectral analysis of the carotenoid and its newly synthesized metabolites isolated from the postprandial triglycerides (TG)-rich lipoprotein plasma fraction, are the most promising methods in terms of accurate measurement of carotenoid absorption.

The in vivo intestinal absorption of carotenoids involves several crucial steps: 1) release of carotenoids from the food matrix, 2) solubilization of carotenoids into mixed lipid micelles in the lumen, 3) cellular uptake of carotenoids by intestinal mucosal cells, 4) incorporation of carotenoids into chylomicrons (CM) and 5) secretion of carotenoids and their metabolites associated with CM into the lymph. In this overall process, several basic aspects still remain to be clarified such as the absolute absorption efficiencies of the different carotenoids, the nature of luminal and intracellular factors regulating the process of absorption, the mechanisms of intracellular transport of carotenoids and of their incorporation into CM, and the nature of interactions between carotenoids occurring during their intestinal absorption. Given the limitations of using human subjects for these kinds of investigations, much of our knowledge of the mechanisms of intestinal carotenoid absorption on the molecular level has come from studies of in vitro intestinal cell culture model systems mimicking the in vivo intestinal absorption of carotenoids (steps 3-5 of the above-mentioned steps) [69].

Under normal cell culture conditions, human intestinal Caco-2 cells are unable to form CM. However, when supplemented with oleic acid (OA) and taurocholate (TC) [110], highly differentiated parent Caco-2 cells (without BCO1 activity) and the derived TC7 cells (with BCO1 activity) cultured on membranes were able to form and secrete CM. The high OA concentration is necessary to induce intracellular TG synthesis and thus CM assembly. Because Caco-2 cells were more efficient than TC7 cells in terms of both CM formation and $\beta-C$ transport, and because $\beta-C$ cleavage might complicate studies on provitamin A carotenoid absorption per se, the parent Caco- 2 cell line has been used in most studies. CM secreted by Caco- 2 cells were characterized as particles rich in (newly synthesized) TG ( $\sim 90 \%$ of total secreted) containing apolipoprotein B ( $30 \%$ of total secreted) and phospholipids ( $\sim 20 \%$ of total secreted) and with an average diameter of $\sim 60 \mathrm{~nm}$ (determined by laser light scattering) [69,70]. These characteristics are similar to those of CM secreted in vivo by the enterocytes.

Based on early rat studies, the intestinal absorption of carotenoids was thought to be a passive diffusion process determined by the concentration gradient of the carotenoid across the intestinal membrane. The kinetics of $\beta-C$ transport through Caco- 2 cell monolayers, characterized for both steps (cellular uptake and secretion in $\mathrm{CM}$ ), showed curvilinear, timedependent and saturable, concentration-dependent (apparent $\mathrm{Km}$ of 7-10 $\mu \mathrm{M}$ ) processes 
[69]. Thus, these data suggested that the intestinal transport of carotenoids might be facilitated by the participation of a specific epithelial transporter.

The saturation of $\beta-C$ transport through Caco- 2 cell monolayers occurred at $\beta-\mathrm{C}$ concentrations of $15-20 \mu \mathrm{M}$, equivalent to a daily $\beta$-C intake of $100 \mathrm{mg}$ or more. It was estimated that the $\beta-\mathrm{C}$ concentration of $1 \mu \mathrm{M}$ at the apical side of cells (or $400 \mathrm{pmol} \beta-\mathrm{C} /$ $\mathrm{cm} 2$ of Caco-2 cell monolayer) was close to the physiological level of $\beta-\mathrm{C}$ found in the gut (200 pmol $\beta-\mathrm{C} / \mathrm{cm}^{2}$ of surface of absorption) after ingestion of a daily $\beta$-C dose of $5 \mathrm{mg}$ [69]. Of the total $\beta-\mathrm{C}$ secreted by Caco-2 cells $80 \%$ was associated with $\mathrm{CM}, 10 \%$ with VLDL and $10 \%$ with the non-lipoprotein fraction [69], pointing to the importance of CM assembly for $\beta-\mathrm{C}$ secretion into the lymph in vivo.

Human studies [71-74] have consistently reported a preferential accumulation of all-trans $\beta$ $\mathrm{C}$ in total plasma, and in the postprandial TG-rich lipoprotein plasma fraction, compared to its 9-cis isomer. These differences in plasma response between the two geometrical isomers suggested either a selective intestinal transport of all-trans $\beta-\mathrm{C}$ versus its 9-cis isomer or an intestinal cis-trans isomerization of 9-cis $\beta$-C into all-trans $\beta$-C. This later possibility was brought up by a study [74] showing a significant accumulation of $\left[{ }^{13} \mathrm{C}\right]$-all-trans $\beta$-C in plasma of subjects who ingested only $\left[{ }^{13} \mathrm{C}\right]-9$-cis $\beta$-C. Starting with an initial concentration $(1 \mu \mathrm{M})$ for the three geometrical isomers of $\beta$-C applied separately to the in vitro system described above, it was demonstrated that both 9-cis and 13-cis $\beta$-C were taken up by Caco- 2 cells to only $1 / 5$ the extent of all-trans $\beta$-C [69]. The extents of absorption of the two cis isomers through Caco-2 cell monolayers were less than $3.5 \%$ (compared to $11 \%$ for all$\operatorname{trans} \beta-\mathrm{C}$ ), indicating that the discrimination between $\beta$-C isomers occurred at the cellular uptake level of the intestinal absorption process.

When Caco-2 cells were incubated with only 9-cis $\beta-\mathrm{C}$, all-trans $\beta$-C did not increase in cells or in the basolateral medium, indicating that there is no cis-trans isomerization occurring in intestinal cells. Thus, the isomerization of 9-cis $\beta$-C observed in vivo [74] could take place in the gastrointestinal lumen before the cellular uptake. The data on the selective uptake of $\beta$-C isomers by Caco- 2 cells also support the idea of a specific transport involved in the intestinal absorption process of carotenoids.

Using in vitro cell culture systems and a range of physiological concentrations $(1-5 \mu \mathrm{M})$, neither LUT nor $\beta$-C affected significantly the transport of each other through Caco- 2 cell monolayers, while the main carotenoid interactions were observed between nonpolar carotenoids ( $\beta-\mathrm{C} / \mathrm{a}-\mathrm{C}$ and $\beta-\mathrm{C} / \mathrm{LYC}$ ). Thus, the specific interactions observed in the in vitro study [69] indicate that two carotenoids exhibiting similar structural characteristics could follow a similar pathway in intestinal cells and thus compete for their cellular uptake. These mutual interactions are also consistent with the idea of a facilitated uptake process.

The concentration dependence (saturation) of $\beta$-C uptake and secretion in $\mathrm{CM}$, the discrimination between $\beta-\mathrm{C}$ isomers for their cellular uptake, the differential absorption of different carotenoids as well as their interactions observed during transport through Caco-2 cells, all suggest that the intestinal transport of carotenoids is facilitated by the participation of a specific epithelial transporter [69]. This idea was supported by the concomitant identification of a scavenger receptor with a high sequence homology to the mammalian class B scavenger receptors (SR-BI and CD36) mediating the cellular uptake of carotenoids in Drosophila [75]. More recent work in Caco-2 cells [8,76-78] has demonstrated a direct role for SR-BI in the cellular uptake of $\beta-C$, LUT and LYC. Moreover, studies of the SR-BI $\mathrm{KO}$ mouse indicate a role for this lipid transporter in the intestinal absorption of $\beta-\mathrm{C}$ in the intact animal [79]. Interestingly, the intestinal absorption of carotenoids and other lipids is 
controlled by RA-induced expression of the transcription factor ISX which then represses expression of SR-BI [50].

\section{Intestinal absorption of vitamin A}

Studies of the uptake of retinol by the human intestinal cell line, Caco-2, indicated that under postprandial conditions (i.e., given oleic acid) retinol was taken up rapidly by these cells and then esterified and the retinyl esters were secreted with chylomicrons [80]. In contrast, under "fasting" conditions the cells do not secrete retinyl esters but secrete retinol not associated with lipoproteins into the basolateral medium.

Other experiments in the author's laboratory have suggested the role of transporters in retinol efflux in Caco-2 cells [8]. When cells were incubated with $3 \mu \mathrm{M}$ retinol for varying times up to $24 \mathrm{~h}$, cellular retinol plateaued within $2 \mathrm{~h}$, whereas there was continuous formation of retinyl esters. Both retinol and retinyl esters secreted in basolateral medium increased linearly with time (up to $20 \mathrm{~h}$ ). Retinyl esters were associated with chylomicrons and retinol with the nonlipoprotein fraction. After incubation with retinol concentrations of $0.5-130 \mu \mathrm{M}$, cellular uptake of retinol was directly proportional to initial retinol concentration. However, the kinetics of efflux of retinol into basolateral medium revealed two processes. Retinol secretion showed saturation at concentrations $<10 \mu \mathrm{M}$, implying a mediated transport out of the cell, and linearity with higher concentrations, implying passive diffusion. One interpretation of these data is that free retinol enters into intestinal cells by simple diffusion, while its secretion may require a facilitated transport at physiological doses. Glyburide, a known inhibitor of the ABCA1 transporter, caused marked inhibition of the efflux of free retinol into basolateral medium (but not cell uptake). Finally, inhibition of ABCA1 protein expression by siRNAs decreased retinol efflux in proportion to the extent of protein knockdown.

Early studies using intestinal segments also suggested that the unesterified retinol was absorbed by protein-mediated facilitated diffusion and passive diffusion mechanisms at physiologic $[<150 \mathrm{nM}]$ and pharmacological concentrations [450-2700 nM], respectively $[81,82]$.

Thus it seems that both carotenoids and retinol join an ever-growing list of fat soluble molecules that are absorbed via the action of membrane-bound lipid transporters. For example, three different membrane-bound proteins, CD36, membrane bound fatty acid binding protein, and a fatty acid transport protein, that are involved in fatty acid uptake have been identified [for review, [83,84]]. In the case of cholesterol, SRB1, CD36, NPC1L1, and a variety of $A B C$ transporters have been implicated in its uptake and/or efflux from various cells [85-90]. It is possible that these or other proteins may play a role in the transport of retinol across cell membranes. Defining the exact mechanisms of cellular uptake of retinol (or other lipids) is complicated by the fact that, as indicated above, multiple mechanisms (both facilitated and passive) may exist in a single cell. An additional problem is that much of the work in this area relies on the use of membrane transporter inhibitors, and there is increasing evidence that some of these compounds inhibit multiple transporters types [91]. A final complication is that some of the transport inhibitors also affect the expression of transporter genes and, thus, exert effects on transporter number and function simultaneously [76].

The general perception that retinol is completely esterified in the mucosal cell and quantitatively transported on chylomicrons may need re-evaluation [for review, [92,93]]. First, it should be pointed out that the recovery of ingested retinol in lymph varies between 20 and $60 \%$ in various studies [12,93]. Second, Hollander showed that approximately $60 \%$ and $30 \%$ of the absorbed retinol is secreted into lymph and portal circulation, respectively 
[94]. Furthermore, he showed that secretion of retinol into lymph was modulated by the presence of different concentrations of taurocholate and different fatty acids [94]. Third, oral supplementation of retinol into abetalipoproteinemia patients, who do not assemble and secrete chylomicrons, results in partial recovery from symptoms of retinol deficiency [95]. Fourth, cell culture studies showed that free retinol or its metabolized products are transported across the cells independent of the assembly and secretion of lipoproteins [80]. Thus, much of the absorbed retinol is secreted into lymph in esterified form. However a significant amount is also secreted into portal circulation probably as free retinol. The transport of free retinol to the portal circulation is expected to be physiologically significant in pathologic conditions that affect the secretion of chylomicrons. Thus, the transport of free retinol may be an essential back-up mechanism for the homoeostasis of vitamin A under some conditions.

After cellular uptake, free retinol is probably immediately sequestered by cellular retinol binding proteins (CRBPs). Two CRBPs, CRBP(I) and CRBP(II) have been purified and characterized extensively. They have considerable sequence identity and belong to a family of lipid binding proteins (the lipocalins). Both of the proteins are highly conserved during evolution indicative of their physiologic importance. These proteins share considerable structural, genetic, and biochemical properties. However, the cellular expression pattern of these proteins is very different. The $\mathrm{CRBP}(\mathrm{I})$, a $14.6 \mathrm{kDa}$ polypeptide, is expressed in many tissues whereas CRBP(II), a $16 \mathrm{kDa}$ polypeptide, is expressed primarily in the absorptive cells of the small intestine. The CRBP(II) is one of the most abundant proteins and accounts for approximately $1 \%$ of the total soluble proteins recovered from the jejunal mucosa. The tissue distribution and abundance indicate that it must be uniquely suited for retinol absorption by the intestine [for reviews, [96-98]].

In vitro studies indicated that CRBP(II) can play several functions in the trafficking of retinol. It has been speculated that it can bind to specific transporters on the brush border membrane and permit facilitated diffusion. It can serve as a reservoir to keep the concentrations of free retinoids very low and protect cells from their detergent-like properties. More importantly, it may present retinoids to different enzymes and direct their metabolism $[98,99]$.

In vivo studies showed that CRBP(II) mRNA levels are increased in the small intestine of the retinoid-deficient rats [100], and rats fed with long chain fatty acids [101]. In Caco-2 cells, CRBP(II) mRNA was shown to be increased (2- to 3-fold) after treatment of the differentiated cells with retinoic acid [102]. More importantly, this resulted in increased absorption and intracellular esterification of radiolabeled retinol. Furthermore, absorption and esterification were also increased after the over expression of CRBP(II) in these cells [103]. These studies indicate that changes in CRBP(II) expression result in the modulation of retinol metabolism. However, it is not known whether the increased expression of CRBPII results in increased secretion of retinyl esters in chylomicrons.

The characterization of the CRBPII knockout mouse has clarified that CRBPII plays an important, but not absolutely essential, role in the intestinal absorption of vitamin A [104]. Thus, the saturable component of retinol uptake by jejunal segments was reduced to about half that of tissue from WT littermates [104]. The CRBPII KO mice, when maintained on a vitamin A-enriched diet, also had reduced (about 40\%) hepatic stores of vitamin A, suggesting that the incomplete impairment of retinol processing in the intestine nonetheless affects whole body vitamin A status.

Early studies in intact rats and humans clearly demonstrated that after uptake of newlyabsorbed retinol, the retinol was largely reesterified with long chain fatty acids (mostly 
palmitate) and secreted into the lymphatics along with other dietary lipids in chylomicrons. In enterocytes two enzymes, lecithin:retinol acyl transferase (LRAT) and acyl-coA acyltransferase (ARAT), have been identified that can catalyze the esterification of free retinol in vivo $[10,99]$. It has been suggested, but not shown, that retinyl esters formed by LRAT and ARAT may be targeted for secretion with chylomicron and storage, respectively $[92,93]$. The characterization of the LRAT KO mouse has clearly demonstrated that LRAT plays the major physiological role in retinol esterification [99,105]. However, it is also clear that diacylglycerol acyltransferase 1 (DGAT1) acts as an intestinal ARAT involved in the esterification of retinol especially when pharmacologic doses of retinol are given to animals [99].

It is generally believed that retinol is mainly secreted into the lymph as retinyl palmitate. During metabolic studies, analysis of the plasma revealed that most of the retinyl esters are present in small chylomicrons [106]. Significant amounts of retinyl esters are also found in large chylomicrons followed by smaller amounts in very low-density lipoproteins [106]. In contrast to triglycerides, cholesterol esters and other lipids, retinyl esters are not present in other lipoproteins such as intermediate density lipoproteins, low-density lipoproteins or high-density lipoproteins. These studies indicate that retinyl esters are mainly present in large and small chylomicrons and behave very differently from other neutral lipids, such as triglycerides and cholesterol esters.

To understand the mechanism of secretion of RE by the intestine under the fasting and postprandial states, studies were conducted where differentiated Caco-2 cells were supplemented with radiolabeled retinol under conditions that support (postprandial) or do not support (fasting) chylomicron secretion [80]. These cells assimilated vitamin A by a very rapid uptake mechanism under both conditions. After uptake, the cells stored retinol in both esterified and un-esterified forms. Under fasting conditions, the cells mainly secreted variable amounts of free retinol unassociated with lipoproteins. However, under postprandial conditions, these cells secreted significant amounts of retinyl esters mainly with chylomicrons. The secretion of RE with chylomicrons was independent of the rate of uptake of retinol, intracellular free and esterified retinol levels, and was dependent on the assembly and secretion of chylomicrons. The secretion of RE was correlated with the secretion of chylomicrons and not with the secretion of total apoB. Inhibition of chylomicron secretion by Pluronic L81 decreased the secretion of RE and did not result in their increased secretion with smaller lipoproteins. These data strongly suggest that RE secretion by the intestinal cells is a highly specific and regulated process that is dependent on the assembly and secretion of chylomicrons. These data also indicate that the incorporation of retinyl esters into chylomicrons is not a passive process but is an exquisitely-orchestrated event. Retinyl ester secretion does not occur at all times. It is induced when cells can assemble and secrete chylomicrons. Thus, it appears that intestinal cells may have a specific mechanism for the targeting of retinyl esters to nascent chylomicrons.

As discussed above Caco-2 cells do not secrete retinyl esters under conditions simulating a fasting state. In work on the kinetics of retinol uptake by $\mathrm{Caco} 2$ cells, we conducted a 5-day "washout" experiment in which cells were incubated with retinol for $16 \mathrm{~h}$ to accumulate cellular retinol and retinyl esters and then incubated with retinoid-free medium (containing fatty acids and thus mimicking the "fed" state) that was changed every $24 \mathrm{~h} \mathrm{[8].} \mathrm{This}$ resulted in the release of the free retinol, but not the accumulated retinyl esters. This implies that only newly-synthesized retinyl are incorporated into chylomicrons and that preformed retinyl esters cannot be used for CM assembly. Thus, the synthesis of retinyl esters and their incorporation into chylomicrons appear to be concerted processes. Due the specificity of the secretion of retinyl esters, it was proposed that retinyl esters can be used as signposts to study chylomicron assembly $[107,108]$. 


\section{Summary}

Fig. 2 gives an overview of the mechanisms involved in the intestinal metabolism of vitamin $\mathrm{A}$ and carotenoids. It emphasizes the many proteins that participate in these processes. These are also summarized in Table 1. Given the important role of these proteins in the absorption of dietary carotenoids, their conversion to vitamin A, and the incorporation of both carotenoids and RE into CM, it is not surprising that recent work shows that polymorphisms in these genes affect carotenoid transport and metabolism [49,52]. Thus, single nucleotide polymorphisms in SR-BI [109] and in BCO1 [110,111] have been associated with alterations in whole-body carotenoid and retinoid metabolism in humans. We can expect that future studies will clarify the genetic basis of the differences in efficiency in carotenoid and vitamin A metabolism among humans.

\section{Acknowledgments}

I thank the current and former students, fellows, and colleagues for their contributions to the work from our laboratory that is reviewed here. I also thank the NIH for grant support of the studies in our laboratory (R01DK044498 and R01-HL049867).

\section{Abbreviations}

\begin{tabular}{ll} 
ARAT & acyl \\
CoA & retinol acyltransferase \\
BCO1 & $\beta$-carotene $15,15^{\prime}$-oxygenase \\
BCO2 & $\beta$-carotene $9^{\prime} 10^{\prime}$-oxygenase 2 \\
$\beta$-C & $\beta$-carotene \\
a-C & a-carotene \\
CEL & carboxyl ester lipase \\
CEL KO & CEL, knockout mice \\
CRBP & cellular retinol-binding protein \\
CM & chylomicrons \\
DGAT & diacylglycerol acyltransferase \\
KO & knock out \\
LRAT & lecithin:retinol acyltransferase \\
LUT & lutein \\
LYC & lycopene \\
OA & oleic acid \\
PTL & pancreatic triglyceride lipase \\
PLRP & pancreatic lipase-related protein \\
RA & retinoic acid \\
REH & retinyl ester hydrolase \\
RE & retinyl esters \\
TG & triglycerides \\
\hline
\end{tabular}




$\begin{array}{ll}\text { TC } & \text { taurocholate } \\ \text { VLDL } & \text { very low density lipoproteins } \\ \text { WT } & \text { wild type } \\ \text { ZEA } & \text { zeaxanthin }\end{array}$

\section{References}

1. Miller M, Humphrey J, Johnson E, Marinda E, Brookmeyer R, Katz J. Why do children become vitamin A deficient? J. Nutr. 2002; 132:2867S-2880S. [PubMed: 12221263]

2. Sommer A, Davidson FR. Assessment and control of vitamin A deficiency: the Annecy Accords. J. Nutr. 2002; 132:2845S-2850S. [PubMed: 12221259]

3. Goodwin, TW. The Biosynthesis of Vitamin A and Related Compounds. London: Academic Press; 1963. p. 270-319.

4. Goodwin, TW. Biosynthesis. In: Isler, O., editor. Carotenoids. Basel: Birkhauser Verlag; 1971. p. 577-586.

5. Paik J, During A, Harrison EH, Mendelsohn CL, Lai K, Blaner WS. Expression and characterization of a murine enzyme able to cleave $\beta$-carotene: the formation of retinoids. J. Biol. Chem. 2001; 276:32160-32168. [PubMed: 11418584]

6. Blomstrand R, Werner B. Studies on the intestinal absorption of radioactive betacarotene and vitamin A in man. Conversion of beta-carotene into vitamin A. Scand. J. Clin. Lab. Invest. 1967; 19:339-345. [PubMed: 6051928]

7. Plack PA. Occurence, absorption and distribution of vitamin A. Proc. Nutr. Soc. (Engl. Scot.). 1965; 24:146-154.

8. During A, Harrison EH. Mechanisms of provitamin A (carotenoid) and vitamin A (retinol) transport into and out of intestinal Caco-2 cells. J. Lipid Res. 2007; 48:2283-2294. [PubMed: 17644776]

9. MacDonald PN, Ong DE. Evidence for a lecithin-retinol acyltransferase activity in the rat small intestine. J. Biol. Chem. 1988; 263:12478-12482. [PubMed: 3410848]

10. O'Byrne SM, Wongsiriroj N, Liebien J, Vogel S, Goldberg IJ, Baehr W, Palczewski K, Blaner WS. Retinoid absorption and storage is impaired in mice lacking lecithin:retinol acyltransferase (LRAT). J. Biol. Chem. 2005; 280:35647-35657. [PubMed: 16115871]

11. Harrison EH, Hussain MM. Mechanisms involved in the intestinal digestion and absorption of dietary vitamin A. J. Nutr. 2001; 131:1405-1408. [PubMed: 11340090]

12. Huang HS, Goodman DS. Vitamin A and carotenoids. I. Intestinal absorption and metabolism of ${ }^{14}$ C-labeled vitamin A alcohol and $\beta$-carotene in the rat. J. Biol. Chem. 1965; 240:2839-2844. [PubMed: 14342304]

13. Hazzard WR, Bierman EL. Delayed clearance of chylomicron remnants following vitamin Acontaining oral fat loads in broad-beta disease (type III hyperlipoproteinemia). Metab. Clin. Exp. 1976; 25:777-801. [PubMed: 181657]

14. Hussain MM, Kancha RK, Zhou Z, Luchoomun J, Zu H, Bakillah A. Chylomicron assembly and catabolism: role of apolipoproteins and receptors. Biochim. Biophys. Acta. 1996; 130(1976):151170. [PubMed: 8679680]

15. Blomhoff R, Helgerud P, Rasmussen M, Berg T, Norum KR. In vivo uptake of chylomicron $\left[{ }^{3} \mathrm{H}\right]$ retinyl ester by rat liver: evidence for retinol transfer from parenchymal to nonparenchymal cells. Proc. Natl. Acad. Sci. (U.S.A.). 1982; 79:7326-7330. [PubMed: 6961410]

16. Harrison EH, Gad MZ, Ross AC. Hepatic uptake and metabolism of chylomicron retinyl esters: probable role of plasma membrane/endosomal retinyl ester hydrolases. J. Lipid Res. 1995; 36:1498-1506. [PubMed: 7595074]

17. Lawrence CW, Crain FD, Lotspeich FJ, Krause RF. Absorption, transport, and storage of retinyl-15- ${ }^{14} \mathrm{C}$ palmitate-9,10- ${ }^{3} \mathrm{H}$ in the rat. J. Lipid Res. 1966; 7:226-229. [PubMed: 5947036] 
18. Wirtz GM, Bornemann C, Giger A, Muller RK, Schneider H, Schlotterbeck G, Schiefer G, Woggon W-D. The substrate specificity of $\beta, \beta$-carotene $15,15^{\prime}$-monooxygenase. Helv. Chim. Acta. 2001; 84:2301-2315.

19. Bauernfeind JC. Carotenoid vitamin A precursors and analogs in foods and feeds. J. Agric. Food Chem. 1972; 20:456-473.

20. van Vliet T, van Schaik F, Schreurs WHP, van den Berg H. In vitro measurement of beta-carotene cleavage activity: methodological considerations and the effect of other carotenoids on betacarotene cleavage. Int. J. Vitam. Nutr. Res. 1996; 66:77-85. [PubMed: 8698551]

21. Nagao A, Olson JA. Enzymatic formation of 9-cis, 13-cis, and all-trans retinals from isomers of beta-carotene. FASEB J. 1994; 8:968-973. [PubMed: 8088462]

22. US Department of Agriculture; Agricultural Research Service. USDA Nutrient Database for Standard Reference, Release, 17, 2004. Nutrient Data Laboratory Homepage. http:// www.nal.usda.gov/fnic/foofcomp.

23. US Institute of Medicine. Food and Nutrition Board. Dietary Reference Intakes for Vitamin A, Vitamin K, Arsenic, Boron, Chromium, Copper, Iodine, Iron, Manganese, Molybdenum, Nickel, Silicon, Vanadium, and Zinc. Washington: National Academy Press; 2002.

24. US Department of Agriculture; Agricultural Research Service. What We Eat in America, NHANES 2001-2002. Food Surveys Research Group. 2004

25. Li E, Tso P. Vitamin A uptake from foods. Curr. Opin. Lipidol. 2003; 14:241-247. [PubMed: 12840654]

26. Unlu NZ, Bohn T, Clinton SK, Schwartz SJ. Carotenoid absorption from salad and salsa by humans is enhanced by the addition of avocado or avocado oil. J. Nutr. 2005; 135:431-436. [PubMed: 15735074]

27. Olson JA, Hayaishi O. The enzymatic cleavage of beta-carotene into vitamin A by soluble enzymes of rat liver and intestine. Proc. Natl. Acad. Sci. U.S.A. 1965; 54:1364-1370. [PubMed: 4956142]

28. Leuenberger MG, Engeloch-Jarret C, Woggon W-D. The reaction mechanism of the enzymecatalyzed central cleavage of beta-carotene to retinal. Angew. Chem. Int. Ed. 2001; 40:2614-2617.

29. Devery J, Milborrow BV. Beta-carotene-15,15' -dioxygenase (EC 1.13.11.21) isolation reaction mechanism and an improved assay procedure. Brit. J. Nutr. 1994; 72:394-414.

30. Nagao A, During A, Hoshino C, Terao J, Olson JA. Stoichiometric conversion of all trans-betacarotene to retinal by pig intestinal extract. Arch. Biochem. Biophys. 1996; 328:57-63. [PubMed: 8638938]

31. von Lintig J, Vogt K. Filling the gap in vitamin A research. Molecular identification of an enzyme cleaving beta-carotene to retinal. J. Biol. Chem. 2000; 275:11915-11920. [PubMed: 10766819]

32. Wyss A, Wirtz G, Woggon W-D, Brugger R, Wyss M, Friedlein A, Bachmann H, Hunziker W. Cloning and expression of beta, beta-carotene 15,15' -dioxygenase. Biochem. Biophys. Res. Commun. 2000; 271:334-336. [PubMed: 10799297]

33. Redmond TM, Gentleman S, Duncan T, Yu S, Wiggert B, Gantt E, Cunningham FX. Identification, expression, and substrate specificity of a mammalian betacarotene $15,15^{\prime}$ dioxygenase. J. Biol. Chem. 2001; 276:6560-6565. [PubMed: 11092891]

34. Wyss A, Wirtz G, Woggon W-D, Brugger R, Wyss M, Friedlein A, Bachmann H, Hunziker W. Expression pattern and localization of beta, beta-carotene $15,15^{\prime}$-dioxygenase in different tissues. Biochem. J. 2001; 354:521-529. [PubMed: 11237856]

35. Yan W, Jang G-F, Haeseleer F, Esumi N, Chang J, Kerrigan M, Campochiaro M, Campochiaro P, Palczewski K, Zack DJ. Cloning and characterization of a human beta, beta-carotene-15,15' dioxygenase that is highly expressed in the retinal pigment epithelium. Genomics. 2001; 72:193202. [PubMed: 11401432]

36. Lindqvist A, Andersson S. Biochemical properties of purified recombinant human beta-carotene 15,15' -monooxygenase. J. Biol. Chem. 2002; 277:23942-23948. [PubMed: 11960992]

37. Barua $\mathrm{AB}$, Olson JA. Beta-carotene is converted primarily to retinoids in rats in vivo. J. Nutr. 2000; 130:1996-2001. [PubMed: 10917914] 
38. Handelman GJ, van Kuijk FJ, Chatterjee A, Krinsky NI. Characterization of products formed during the autoxidation of beta-carotene. Free Radic. Biol. Med. 1991; 10:427-437. [PubMed: 1894165]

39. Kiefer C, Hessel S, Lampert JM, Vogt K, Lederer MO, Breithaupt DE, von Lintig J. Identification and characterization of a mammalian enzyme catalyzing the asymmetric oxidative cleavage of provitamin A. J. Biol. Chem. 2001; 276:14110-14116. [PubMed: 11278918]

40. Yeum KJ, dos Anjos Ferreira AL, Smith D, Krinsky NI, Russell RM. The effect of alphatocopherol on the oxidative cleavage of beta-carotene. Free Radic. Biol. Med. 2000; 29:105-114. [PubMed: 10980399]

41. During A, Smith MK, Piper JB, Smith JC. Beta-carotene 15,15' -dioxygenase activity in human tissues and cells: evidence of an iron dependency. J. Nutr. Biochem. 2001; 12:640-647. [PubMed: 12031257]

42. Novotny JA, Dueker SR, Zech LA, Clifford AJ. Compartmental analysis of the dynamics of betacarotene metabolism in an adult volunteer. J. Lipid Res. 1995; 36:1825-1838. [PubMed: 7595103]

43. During A, Nagao A, Hoshino C, Terao J. Assay of beta-carotene 15,15' -dioxygenase activity by reverse-phase high-pressure liquid chromatography. Anal. Biochem. 1996; 241:199-205. [PubMed: 8921188]

44. van Vliet T, van Vlissingen MF, van Schaik F, van den Berg H. Beta-carotene absorption and cleavage in rats is affected by the vitamin A concentration of the diet. J. Nutr. 1996; 126:499-508. [PubMed: 8632224]

45. During A, Nagao A, Terao J. Beta-carotene $15,15^{\prime}$-dioxygenase activity and cellular retinolbinding protein type II level are enhanced by dietary unsaturated triacylglycerols in rat intestines. J. Nutr. 1998; 128:1614-1619. [PubMed: 9772126]

46. During A, Fields M, Lewis CG, Smith JC. Intestinal beta-carotene 15,15' -dioxygenase activity is markedly enhanced in copper-deficient rats fed on high-iron diets and fructose. Br. J. Nutr. 2000; 84:117-124. [PubMed: 10961168]

47. Gronowska-Senger A, Wolf G. Effect of dietary protein on the enzyme from rat and human intestine which converts beta-carotene to retinal. J. Nutr. 1970; 100:300-308. [PubMed: 5436220]

48. Bachmann H, Desbarats A, Pattison P, Sedgewick M, Riss G, Wyss A, Cardinault N, Duszka C, Goralczyk R, Grolier P. Feedback regulation of beta-carotene $15,15^{\prime}$-monooxygenase by retinoic acid in rats and chickens. J. Nutr. 2002; 132:3616-3622. [PubMed: 12468597]

49. von Lintig J. Colors with functions: elucidating the biochemical and molecular basis of carotenoid metabolism. Ann. Rev. Nutr. 2010; 30:35-56. [PubMed: 20415581]

50. Lobo GP, Hessel S, Eichinger A, Noy N, Moise AR, Wyss A, Palczewski K, von Lintig J. ISX is a retinoic acid-sensitive gatekeeper that controls intestinal $\beta, \beta$-carotene absorption and vitamin $\mathrm{A}$ production. FASEB J. 2010; 24:1656-1666. [PubMed: 20061533]

51. Leitz G, Lange J, Rimbach G. Molecular and dietary regulation of $\beta, \beta$-carotene $15,15^{\prime}$ monooxygenase 1 (BCMO1). Arch. Biochem. Biophys. 2010; 502:8-16. [PubMed: 20599666]

52. Erlanson C, Borgstrom B. The identity of vitamin A esterase activity of rat pancreatic juice. Biochim. Biophys. Acta. 1968; 167:629-631. [PubMed: 5722287]

53. Borgstrom B, Erlanson C. Pancreatic lipase and co-lipase. Interactions and effects of bile salts and other detergents. Eur. J. Biochem. 1973; 37:60-68. [PubMed: 4738093]

54. van Bennekum AM, Li L, Piantedosi R, Shamir R, Vogel S, et al. Carboxyl ester lipase overexpression in rat hepatoma cells and CEL-deficiency in mice have no impact on hepatic uptake or metabolism of chylomicron retinyl ester. Biochemistry. 1999; 38:4150-4156. [PubMed: 10194331]

55. Weng W, Li L, van Bennekum AM, Potter SH, Harrison EH, et al. Intestinal absorption of dietary cholesteryl ester is decreased but retinyl ester absorption is normal in carboxyl ester lipase knockout mice. Biochemistry. 1999; 38:4143-4149. [PubMed: 10194330]

56. van Bennekum AM, Fisher EA, Blaner WS, Harrison EH. Hydrolysis of retinyl esters by pancreatic triglyceride lipase. Biochemistry. 2000; 39:4900-4906. [PubMed: 10769148]

57. Reboul E, Berton A, Moussa M, Kreuzer C, Crenon I, Borel P. Pancreatic lipase and pancreatic lipase-related protein 2, but not pancreatic lipase-related protein 1, hydrolyze retinyl palmitate in physiological conditions. Biochim. Biophys. Acta. 2006; 1761:4-10. [PubMed: 16497549] 
58. Rigtrup KM, McEwen LR, Said HM, Ong DE. Retinyl ester hydrolytic activity associated with human intestinal brush border membranes. Am. J. Clin. Nutr. 1994; 60:111-116. [PubMed: 8017323]

59. Rigtrup KM, Ong DE. A retinyl ester hydrolytic activity intrinsic to the brush border membrane of rat small intestine. Biochemistry. 1992; 31:2920-2926. [PubMed: 1550818]

60. Rigtrup KM, Kakkad B, Ong DE. Purification and partial characterization of retinyl ester hydrolase from brush border of rat small intestinal mucosa: probable identity with brush border phospholipase B. Biochemistry. 1994; 33:2661-2666. [PubMed: 8117729]

61. Ho CC, de Moura FF, Kim SH, Burri BJ, Clifford AJ. A minute dose of ${ }^{14} \mathrm{C}-\beta$-carotene is absorbed and converted to retinoids in humans. J. Nutr. 2010; 139:1480-1486. [PubMed: 19535418]

62. Yeum KJ, Russell RM. Carotenoid bioavailability and bioconversion. Ann. Rev. Nutr. 2002; 22:483-504. [PubMed: 12055355]

63. Van Vliet T. Absorption of beta-carotene and other carotenoids in humans and animal models. Eur. J. Clin. Nutr. 1996; 50:S32-S37. [PubMed: 8841772]

64. Ho CC, de Moura FF, Kim SH, Clifford AJ. Excentral cleavage of betacarotene in vivo in a healthy man. Am. J. Clin. Nutr. 2007; 85:770-777. [PubMed: 17344499]

65. Wang X-D, Krinsky NI, Marini RP, Tang G, Yu J, Hurley R, Fox JG, Russell RM. Intestinal uptake and lymphatic absorption of beta-carotene in ferrets: a model for human beta-carotene metabolism. Am. J. Physiol. 1992; 263:G480-G486. [PubMed: 1415707]

66. Poor CL, Bierer TL, Merchen NR, Fahey GC, Murphy MR, Erdman JW. Evaluation of the preruminant calf as a model for the study of human carotenoid metabolism. J. Nutr. 1992; 122:262-268. [PubMed: 1732467]

67. Pollack J, Campbell JM, Potter SM, Erdman JW. Mongolian gerbils (Meriones unguiculatus) absorb beta-carotene intact from a test meal. J. Nutr. 1994; 124:869-873. [PubMed: 8207544]

68. Lee CM, Boileau AC, Boileau MTW, Williams AW, Swanson KS, Heintz KA, Erdman JW. Review of animal models in carotenoid research. J. Nutr. 1999; 129:2271-2277. [PubMed: 10573562]

69. During A, Hussain MM, Morel DW, Harrison EH. Carotenoid uptake and secretion by CaCo-2 cells: beta-carotene isomer selectivity and carotenoid interactions. J. Lipid Res. 2002; 43:10861095. [PubMed: 12091493]

70. Luchoomun J, Hussain MM. Assembly and secretion of chylomicrons by differentiated Caco-2 cells. Nascent triglycerides and preformed phospholipids are preferentially used for lipoprotein assembly. J. Biol. Chem. 1999; 274:19565-19572. [PubMed: 10391890]

71. Stahl W, Schwarz W, von Laar J, Sies H. All-trans beta-carotene preferentially accumulates in human chylomicrons and very low density lipoproteins compared with the 9-cis geometrical isomer. J. Nutr. 1995; 125:2128-2133. [PubMed: 7643247]

72. Gaziano JM, Johnson EJ, Russell RM, Manson JE, Stampfer MJ, Ridker PM, Frei B, Hennekens $\mathrm{CH}$, Krinsky NI. Discrimination in absorption or transport of beta32 carotene isomers after oral supplementation with either all-trans- or 9-cis-beta-carotene. Am. J. Clin. Nutr. 1995; 61:12481252. [PubMed: 7762525]

73. Johnson EJ, Qin J, Krinsky NI, Russell RM. Beta-carotene isomers in human serum, breast milk and buccal mucosa cells after continuous oral doses of all-trans and 9-cis beta-carotene. J. Nutr. 1997; 127:1993-1999. [PubMed: 9311956]

74. You C-S, Parker RS, Goodman KJ, Swanson JE, Corso TN. Evidence of cistrans isomerization of 9-cis-beta-carotene during absorption in humans. Am. J. Clin. Nutr. 1996; 64:177-183. [PubMed: 8694017]

75. Kiefer C, Sumser E, Wernet MF, von Lintig J. A class B scavenger receptor mediates the cellular uptake of carotenoids in Drosophila. Proc. Natl. Acad. Sci. U.S.A. 2002; 16:10581-10586. [PubMed: 12136129]

76. During A, Dawson HD, Harrison EH. Carotenoid transport is decreased and expression of lipid transporters SR-BI, NPCL1L1, and ABCA1 is down-regulated in Caco-2 treated with ezetimibe. J. Nutr. 2005; 135:2305-2312. [PubMed: 16177187] 
77. Reboul E, Abou L, Mikail C, Ghiringhelli O, Andre M, Portugal H, Jourdheuil-Rahmani D, Amiot M-J, Lairon D, Borel P. Lutein transport by Caco-2 TC-7 cells occurs partly by a facilitated process involving the scavenger receptor class B type I (SR-BI). Biochem. J. 2005; 387:455-461. [PubMed: 15554873]

78. Moussa M, Landrier J-F, Reboul E, Ghiringhelli O, Comera C, Collet X, Frohlich K, Bohm V, Borel P. Lycopene absorption in human intestinal cells and in mice involves scavenger receptor class B type I but not Niemann-Pick C1-like 1. J. Nutr. 2008; 138:1432-1436. [PubMed: 18641187]

79. van Bennekum A, Werder M, Thuahnai ST, Han C-H, Duong P, Williams DL, Wettstein P, Schulthess G, Phillips MC, Hauser H. Class B scavenger receptor-mediated intestinal absorption of dietary $\beta$-carotene and cholesterol. Biochemistry. 2005; 44:4517-4525. [PubMed: 15766282]

80. Nayak N, Harrison EH, Hussain MM. Retinyl ester secretion by the intestinal cells is a specific and regulated process that is dependent on the assembly and secretion of chylomicrons. J. Lipid Res. 2001; 42:272-280. [PubMed: 11181758]

81. Hollander D. Intestinal absorption of vitamins A, E, D, and K. J. Lab. Clin. Med. 1981; 97:449462. [PubMed: 7205056]

82. Hollander D, Muralidhara KS. Vitamin A1 intestinal absorption in vivo: influence of luminal factors on transport. Am. J. Physiol. 1977; 232:E471-E477. [PubMed: 16498]

83. Abumrad N, Harmon C, Ibrahimi A. Membrane transport of long-chain fatty acids: evidence for a facilitated process. J. Lipid Res. 1998; 39:2309-2318. [PubMed: 9831619]

84. Glatz CJF, van Nieuwenhoven FA, Luiken JJFP, Schaap FG, van der Vusse GJ. Role of membrane-associated and cytoplasmic fatty acid-binding proteins in cellular fatty acid metabolism. Prostaglandins Leukot. Essent. Fatty Acids. 1997; 57:373-378. [PubMed: 9430381]

85. Altmann SW, Davis HR Jr, Zhu LJ, Yao X, Hoos LM, et al. Niemann-Pick C1 Like 1 protein is critical for intestinal cholesterol absorption. Science. 2004; 303:1201-1204. [PubMed: 14976318]

86. Iqbal J, Hussain MM. Intestinal lipid absorption. Am. J. Physiol. Endocrinol. Metab. 2009; 296:E1183-E1194. [PubMed: 19158321]

87. Davis HR Jr, Zhu LJ, Hoos LM, Tetzloff G, Maguire M, et al. Niemann-Pick C1 Like 1 (NPC1L1) is the intestinal phytosterol and cholesterol transporter and a key modulator of whole-body cholesterol homeostasis. J. Biol. Chem. 2004; 279:33586-33592. [PubMed: 15173162]

88. Turley SD, Dietschy LM. Sterol absorption by the small intestine. Curr. Opin. Lipidol. 2003; 14:233-240. [PubMed: 12840653]

89. van Heek M, Farley C, Compton DS, Hoos L, Davis HR. Ezetimibe selectively inhibits intestinal cholesterol absorption in rodents in the presence and absence of exocrine pancreatic function. $\mathrm{Br}$. J. Pharmacol. 2001; 134:409-417. [PubMed: 11564660]

90. Wang DQ. New concepts of mechanisms of intestinal cholesterol absorption. Ann. Hepatol. 2003; 2:113-121. [PubMed: 15115962]

91. Nieland TJ, Chroni A, Fitzgerald ML, Maliga Z, Zannis VI, et al. Cross-inhibition of SR-BI- and ABCA1-mediated cholesterol transport by the small molecules BLT-4 and glyburide. J. Lipid Res. 2004; 45:1256-1265. [PubMed: 15102890]

92. Blomhoff R, Green MH, Berg T. Norum KR transport and storage of vitamin A. Science. 1990; 250:399-404. [PubMed: 2218545]

93. Blomhoff R, Green MH, Green JB, Berg T, Norum KR. Vitamin A metabolism: new perspectives on absorption, transport, and storage. Physiol. Rev. 1991; 71:951-990. [PubMed: 1924551]

94. Hollander D. Retinol lymphatic and portal transport: influence of $\mathrm{pH}$, bile, and fatty acids. Am. J. Physiol. 1980; 239:G210-G214. [PubMed: 7435575]

95. Kane, JP.; Havel, RJ. Disorders of the biogenesis and secretion of lipoproteins containing the B apolipoproteins. In: Scriver, CR.; Beaudet, AL.; Sly, WS.; Valle, D., editors. The Metabolic and Molecular Bases of Inherited Disorders. New York: McGraw-Hill; 1995. p. 1853-1885.

96. Li E, Norris AW. Structure/function of cytoplasmic vitamin A-binding proteins. Annu. Rev. Nutr. 1996; 16:205-304. [PubMed: 8839926]

97. Newcomer ME, Jamison RS, Ong DE. Structure and function of retinoid-binding proteins. Subcell. Biochem. 1998; 30:53-80. [PubMed: 9932510] 
98. Ong DE. Cellular transport and metabolism of vitamin A: roles of the cellular retinoid-binding proteins. Nutr. Rev. 1994; 52:S24-S31. [PubMed: 8202279]

99. Wongsiriroj N, Piantedosi R, Palczewski K, Goldberg IJ, Johnson TP, Li E, Blaner WS. The molecular basis of retinoid absorption: a genetic dissection. J. Biol. Chem. 2008; 283:13510 13519. [PubMed: 18348983]

100. Rajan N, Kidd GL, Talmage DA, Blaner WS, Suhara A, Goodman DS. Cellular retinoic acidbinding protein messenger RNA: levels in rat tissues and localization in rat testis. J. Lipid Res. 1991; 32:1195-1204. [PubMed: 1658177]

101. Suruga K, Suzuki R, Goda T, Takase S. Unsaturated fatty acids regulate gene expression of cellular retinol-binding protein, type II in rat jejunum. J. Nutr. 1995; 125:2039-2044. [PubMed: 7643237]

102. Levin MS, Davis AE. Retinoic acid increases cellular retinol binding protein II mRNA and retinol uptake in the human intestinal Caco-2 cell line. J. Nutr. 1997; 127:13-17. [PubMed: 9040537]

103. Lissoos TW, Davis MS, Levin AE. Vitamin A trafficking in Caco-2 cells stably transfected with cellular retinol binding proteins. Am. J. Physiol. 1995; 268:G224-G231. [PubMed: 7864119]

104. Xueping E, Zhang L, Lu J, Tso P, Blaner WS, et al. Increased neonatal mortality in mice lacking cellular retinol-binding protein II. J. Biol. Chem. 2002; 277:36617-36623. [PubMed: 12138113]

105. Batten ML, Imanishi Y, Maeda T, Tu DC, Moise AR, et al. Lecithin-retinol acyltransferase is essential for accumulation of all-trans-retinyl esters in the eye and in the liver. J. Biol. Chem. 2004; 279:10422-10432. [PubMed: 14684738]

106. Lemieux S, Fontani R, Uffelman KD, Lewis GF, Steiner G. Apolipoprotein B-48 and retinyl palmitate are not equivalent markers of postprandial intestinal lipoproteins. J. Lipid Res. 1998; 39:1964-1971. [PubMed: 9788242]

107. Hussain MM. A proposed model for the assembly of chylomicrons. Atherosclerosis. 2000; 148:115. [PubMed: 10580165]

108. Hussain MM, Kedees MH, Singh K, Athar H, Jamali NZ. Signposts in the assembly of chylomicrons. Front. Biosci. 2001; 6:D320-D331. [PubMed: 11229873]

109. Borel P, Moussa M, Reboul E, Lyan B, Defoort D, Vincent-Baudry S, Maillot M, Gastaldi M, Darmon M, Portugal H, Planells R, Lairon D. Human plasma levels of vitamin E and carotenoids are associated with genetic polymorphisms in genes involved in lipid metabolism. J. Nutr. 2007; 137:2653-2659. [PubMed: 18029479]

110. Ferrucci L, Perry BJR, Matteini A, Perola M, Tanaka T, Silander K, Rice N, Melzer D, Murray A, Cluett C, Fried LP, Albanes D, Corsi A-M, Cherubini A, Guralnik J, Bandinelli S, Singleton A, Virtamo J, Walston J, Semba RD, Fraying TM. Common variation in the $\beta$-carotene $15,15^{\prime}$ monooxygenase 1 gene affects circulating levels of carotenoids: a genome-wide association study. Am. J. Human Gen. 2009; 84:123-133.

111. Leung WC, Hessel S, Meplan C, Flint J, Oberhauser V, Toutniaire F, Hesketh JE, von Lintig J, Leitz G. Two common single nucleotide polymorphisms in the gene encoding $\beta$-carotene $15,15^{\prime}$ monooxygenase alter $\beta$-carotene metabolism in female volunteers. FASEB J. 2009; 23:10411053. [PubMed: 19103647] 


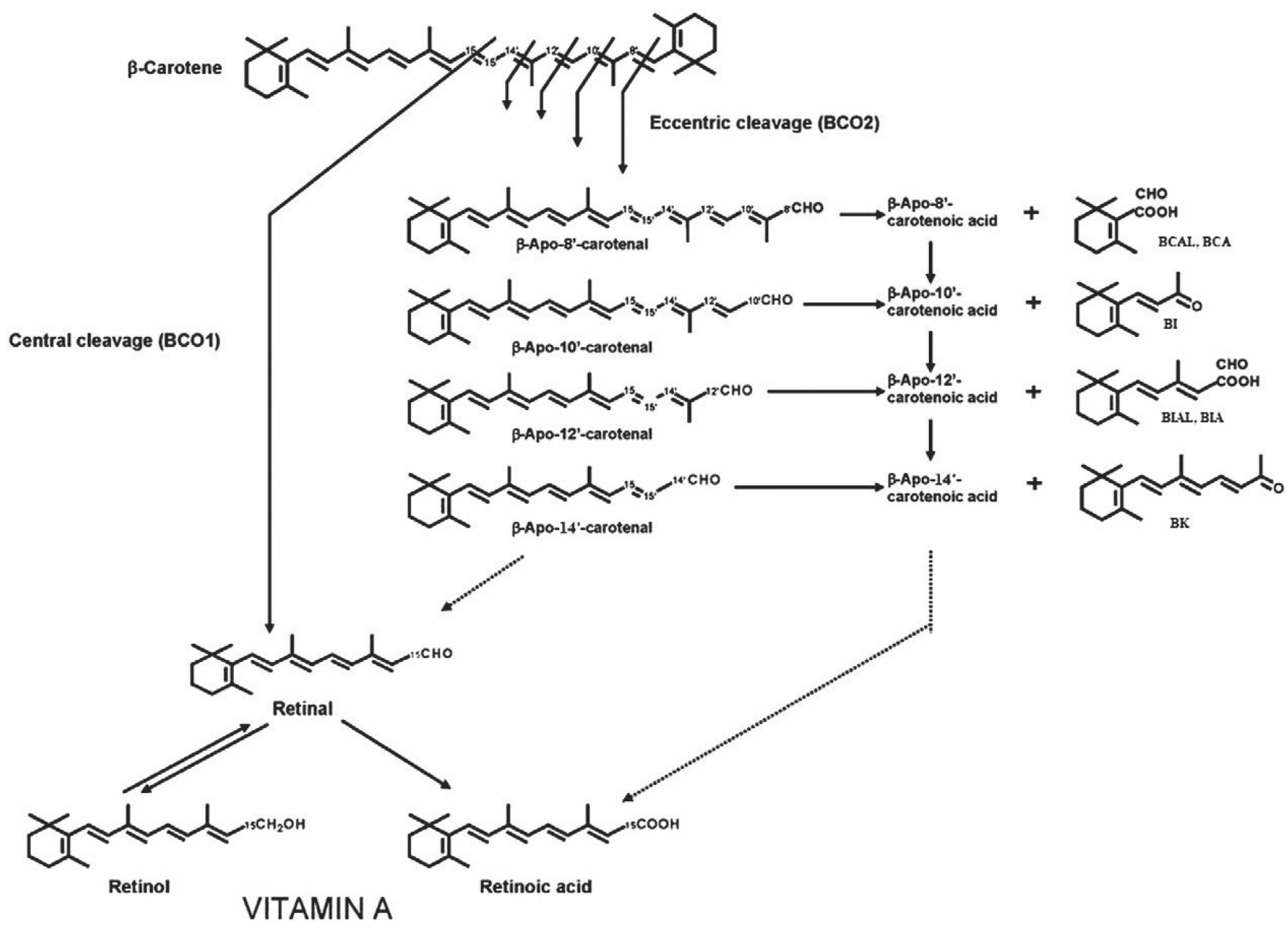

Fig. 1.

Products of the central and eccentric cleavages of $\beta$-carotene. Oxidative cleavage of $\beta$ carotene at the $15,15^{\prime}$ double bond is catalyzed by the enzyme $\beta$-carotene $15,15^{\prime}$-oxygenase 1 (BCO1) and leads to the generation of two molecules of retinal. Cleavage at other double bonds leads to the formation of $\beta$-apocarotenals and $\beta$-apocarotenones. For example the cleavage at the $9^{\prime}, 10^{\prime}$ double bond is catalyzed by $\beta$-carotene $9^{\prime} 10^{\prime}$-oxygenase 2 (BCO2) and leads to the formation of $\beta$-apo-10' ${ }^{\prime}$-carotenal and $\beta$-ionone (BI). Eccentric cleavage at other double bonds may occur nonenzymatically or may be enzyme catalyzed. Presumably the $\beta$-apocarotenals can be oxidized to the corresponding $\beta$-apocarotenoic acids by nonspecific aldehyde dehydrogenases but this has not been clearly demonstrated. The mechanism of possible chain shortening of $\beta$-apocarotenals and $\beta$-apocarotenoic acids (dotted lines) is also not known. 


\section{LUMEN \\ ENTEROCYTE \\ LYMPH/BLOOD}

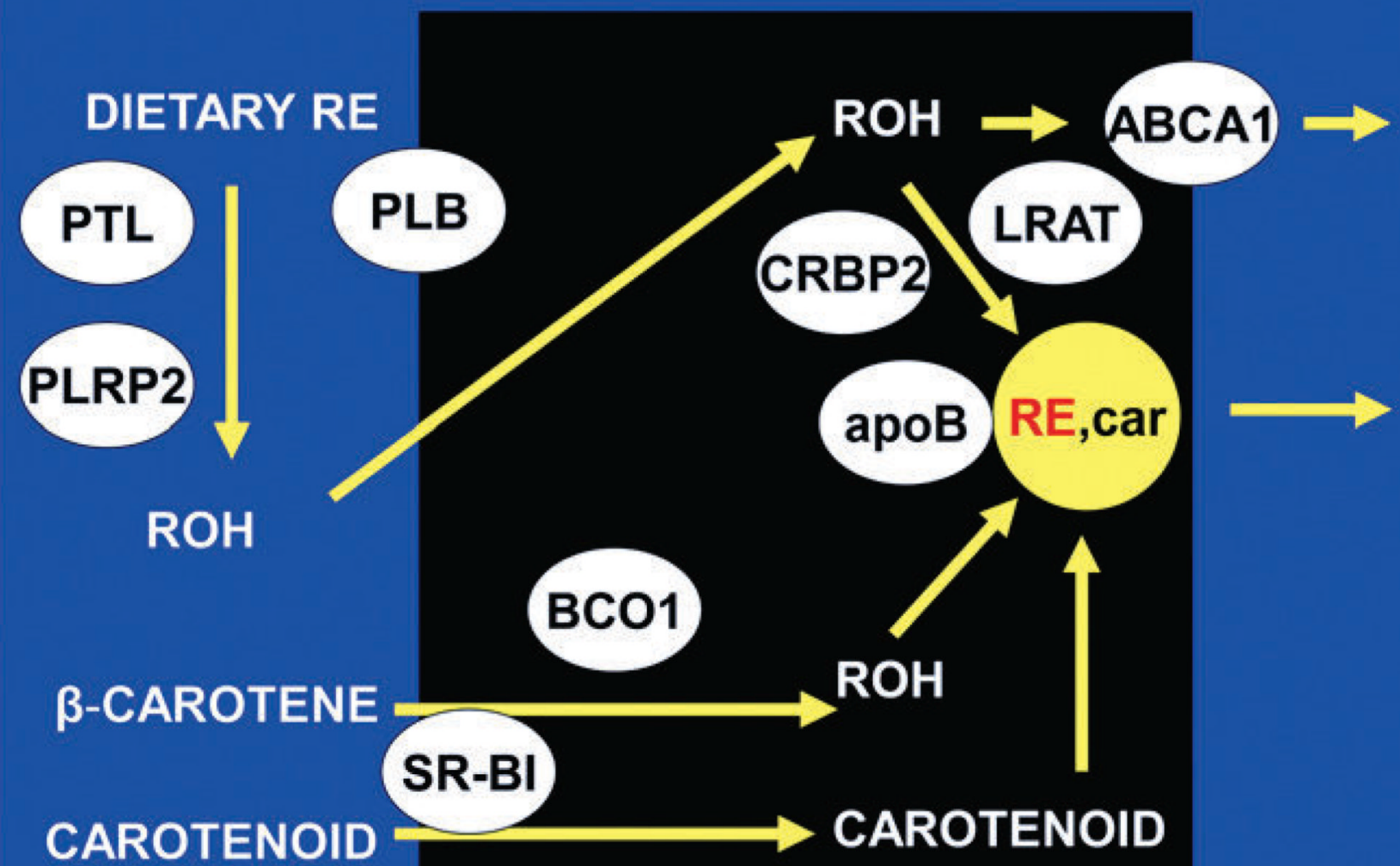

Fig. 2.

Overview of intestinal absorption of dietary vitamin A and carotenoids. Dietary retinyl esters (RE) are hydrolyzed in the lumen by the pancreatic enzymes, pancreatic triglyceride lipase (PTL) and pancreatic lipase-related protein 2 (PLRP2), and the intestinal brush border enzyme, phospholipase B (PLB). Unesterified retinol (ROH) is taken up by the enterocyte, perhaps via passive diffusion. Once in the cell, retinol is complexed with cellular retinolbinding protein type 2 (CRBP2) and the complex serves as a substrate for re-esterification of the retinol by the enzyme lecithin:retinol acyltransferase (LRAT). The RE are then incorporated into chylomicrons, intestinal lipoproteins containing other dietary lipids (such as triglyceride, phospholipids, cholesterol, and cholesteryl esters) and apolipoprotein B (apoB). The incorporation of some of these lipids is dependent on the activity of microsomal triglyceride transfer protein. Dietary provitamin A carotenoids (e.g. $\beta$-carotene) and other carotenoids are taken up by intestinal cells perhaps by facilitated processes involving scavenger receptor class B type I (SR-BI). $\beta$-Carotene is partially converted to retinol by $\beta$ carotene oxygenase 1 (BCO1) and retinal reductase. The retinol so formed is then metabolized like that originating from preformed vitamin A. The intact carotenoids are incorporated into nascent chylomicrons. Chylomicrons containing newly absorbed retinyl esters and carotenoids (RE, car) are then secreted into the lymph. Unesterified retinol is also absorbed into the portal circulation and its efflux from the basolateral cell membrane is facilitated by the lipid transporter, ABCA1. 
Table 1

Proteins involved in the digestion, absorption and transport of dietary vitamin A.

1 Carotenoid cleavage

$\beta$-Carotene oxygenases (BCO1 and BCO2)

2 Carotenoid uptake and transfer

Carotenoid transporters (SRB1, others?)

Carotenoid-binding proteins?

2

Retinyl ester hydrolysis

a. Lumen

Pancreatic triglyceride lipase

Pancreatic lipase-related protein 2

b. Brush border membrane

Phospholipase B

2 Retinol uptake, transfer, and efflux

Retinol transporters (ABCA1, others?)

Cellular retinol binding protein I (?)

Cellular retinol binding protein II

3 Retinyl ester synthesis

Lecithin:retinol acyltransferase

Diacylglycerol acyltransferase 1

4 Chylomicron assembly

Apolipoprotein B

Microsomal triglyceride transfer protein 